\title{
Lower respiration in the littoral zone of a subtropical shallow lake
}

\author{
Ng Haig They ${ }^{1}$, David da Motta Marques ${ }^{2 *}$ and Rafael Siqueira Souza ${ }^{2}$ \\ Programa de Pós-Graduação em Ecologia, Laboratório de Ecotecnologia e Limnologia Aplicada, Instituto de Pesquisas Hidráulicas, Universidade Federal do Rio \\ Grande do Sul, Porto Alegre, Brazil \\ ${ }^{2}$ Laboratório de Ecotecnologia e Limnologia Aplicada, Instituto de Pesquisas Hidráulicas, Universidade Federal do Rio Grande do Sul, Porto Alegre, Brazil
}

Edited by:

André M. Amado, Universidade

Federal do Rio Grande do Norte, Brazil

\section{Reviewed by:}

Alison Buchan, University of

Tenessee-Knoxville, USA

Zongze Shao, State Oceanic

Administration, China

*Correspondence:

David da Motta Marques, Laboratório de Ecotecnologia e Limnologia Aplicada, Instituto de Pesquisas Hidráulicas, Universidade Federal do Rio Grande do Sul, Avenida Bento Gonçalves 9500, Porto Alegre, Rio Grande do Sul 91501-970, Brazil. e-mail:dmm@iph.ufrgs.br
Macrophytes are important sources of dissolved organic carbon (DOC) to littoral zones of lakes, but this DOC is believed to be mostly refractory to bacteria, leading to the hypothesis that bacterial metabolism is different in littoral and pelagic zones of a large subtropical shallow lake. We tested this hypothesis by three approaches: (I) dissolved inorganic carbon (DIC) accumulation in littoral and pelagic water; (II) $\mathrm{O}_{2}$ consumption estimate for a cloud of points ( $n=47$ ) covering the entire lake; (III) measurement of $\mathrm{O}_{2}$ consumption and $\mathrm{CO}_{2}$ accumulation in dark bottles, $\mathrm{pCO}_{2}$ in the water, lake-atmosphere fluxes of $\mathrm{CO}_{2}\left(f \mathrm{CO}_{2}\right)$ and a large set of limnological variables at 19 sampling points (littoral and pelagic zones) during seven extensive campaigns. For the first two approaches, $\mathrm{DIC}$ and $\mathrm{O}_{2}$ consumption were consistently lower in the littoral zone, and $\mathrm{O}_{2}$ consumption increased marginally with the distance to the nearest shore. For the third approach, we found in the littoral zone consistently lower DOC, total phosphorus (TP), and chlorophyll $a$, and a higher proportion of low-molecular-weight substances. Regression trees confirmed that high respiration $\left(\mathrm{O}_{2}\right.$ consumption and $\mathrm{CO}_{2}$ production) was associated to lower concentration of low-molecular-weight substances, while $\mathrm{pCO}_{2}$ was associated to $\mathrm{DOC}$ and TP, confirming that $\mathrm{CO}_{2}$ supersaturation occurs in an attempt to balance phosphorus deficiency of macrophyte substrates. Littoral zone $\mathrm{fCO}_{2}$ showed a tendency to be a $\mathrm{CO}_{2}$ sink, whereas the pelagic zone showed a tendency to act as $\mathrm{CO}_{2}$ source to the atmosphere. The high proportion of low-molecular-weight, unreactive substances, together with lower DOC and TP may impose lower rates of respiration in littoral zones. This effect of perennial stands of macrophytes may therefore have important, but not yet quantified implications for the global carbon metabolism of these lakes, but other issues still need to be carefully addressed before rejecting the general belief that macrophytes are always beneficial to bacteria.

Keywords: bacteria, macrophytes, phosphorus, chlorophyll a, humic substances, $\mathrm{DOC}, \mathrm{CO}_{2}$

\section{INTRODUCTION}

Subtropical shallow lakes may present an important and differentiated set of conditions that make them ecologically distinct from other types of lakes. Because of the shallow mean depths and the benign climate conditions, macrophytes can colonize extensive areas and grow continuously throughout the year. These plants are important sources of organic matter to the littoral zones; in many cases they contribute more carbon than do the algae (Wetzel, 1992; Lauster et al., 2006) and in some systems, they sustain most of the bacterial production (Stanley et al., 2003).

However, macrophyte-derived carbon is believed to be mostly in the form of high-molecular-weight polymer-like compounds (Bracchini et al., 2006), poor in nitrogen and phosphorus contents (Hessen, 1992), and therefore refractory to bacterial consumption. Studies finding that the presence of macrophytes can be detrimental to bacterioplankton are starting to accumulate. Wu et al. (2007) found lower bacterial diversity in submersed macrophytedominated areas than in areas with no macrophytes in the large Lake Taihu, China. Rooney and Kalff (2003) surveyed nine lakes with different percentages of macrophyte coverage, and found a significant decrease in the bacterial respiration rate with increasing macrophyte coverage. In southern Brazil, bacterial metabolism and biovolume were found to be lower in the littoral (covered with macrophytes) than in the pelagic zones of subtropical shallow lakes (They et al., 2010). If bacterial metabolism can be lower in the presence of macrophytes, there is a contradiction with the common belief that macrophyte-derived carbon always benefit bacteria, and it is reasonable to hypothesize that carbon cycling can be affected in the littoral zones of lakes that are extensively colonized by these plants.

Estimates of bacterial respiration are essential to assess the balance of a lake's metabolism because they provide a direct assessment of the fate of carbon within the system, reflecting its transfer from the organic to the inorganic pool (Jahnke and Craven, 1995). It is well established that plankton respiration increases with chlorophyll, phosphorus, and organic carbon concentrations in lakes (Pace and Prairie, 2005). The effect of primary production (in terms of chlorophyll $a$ ) on bacterial production has long 
been recognized, even in systems dominated by terrestrial-carbon inputs (Kritzberg et al., 2005). Phosphorus can also play a role. High rates of respiration and $\mathrm{CO}_{2}$ supersaturation have been associated with high humic content of the carbon pool, because they are an attempt to balance phosphorus deficiency in these lownutrient-content substrates (Hessen, 1992). Moreover, the ratio of phosphorus to labile DOC can control partitioning between bacterial respiration and production (Cimbleris and Kalff, 1998; Smith and Prairie, 2004; del Giorgio and Newell, 2012). DOC concentration, in turn, is also positively associated with $\mathrm{CO}_{2}$ supersaturation in lakes (Prairie et al., 2002).

In the present study, we tested the hypothesis that there is a difference in the general metabolism of carbon in the littoral versus pelagic zones in the large, subtropical shallow Lake Mangueira, through: (a) an experiment to measure dissolved inorganic carbon (DIC) accumulation in littoral and pelagic water; (b) measurement of respiration in a cloud of points covering littoral and pelagic zones; and (c) extensive temporal measurement of respiration, $p \mathrm{CO}_{2}, \mathrm{CO}_{2}$ fluxes, and limnological variables related to bacterial-carbon metabolism in a smaller cloud of points, also covering the whole lake.

\section{MATERIALS AND METHODS STUDY SITE}

Lake Mangueira (80,800 ha, southern Brazil, state of Rio Grande do Sul) is a large, shallow, freshwater subtropical coastal lake. It is surrounded by extensive belts of wetlands, located primarily in the northern and southern areas. The DIC accumulation experiment (to test question a above) was done in the southernmost part of the lake, and the two clouds of points (to test questions b and $c$ above) covered the entire lake (Figure 1).

\section{DIC ACCUMULATION IN LITTORAL $x$ PELAGIC WATER}

Samples of pelagic and littoral water were collected and incubated for 14 days for determination of the cumulative DIC, in April-May 2007. We retrieved vials at days 0, 1, 3, 5, 7, 10, and 14 , in triplicates $(n=42)$. The incubation vials (sterile $40 \mathrm{~mL}$ clear borosilicate vials, open top with silicone/PTFE septum and

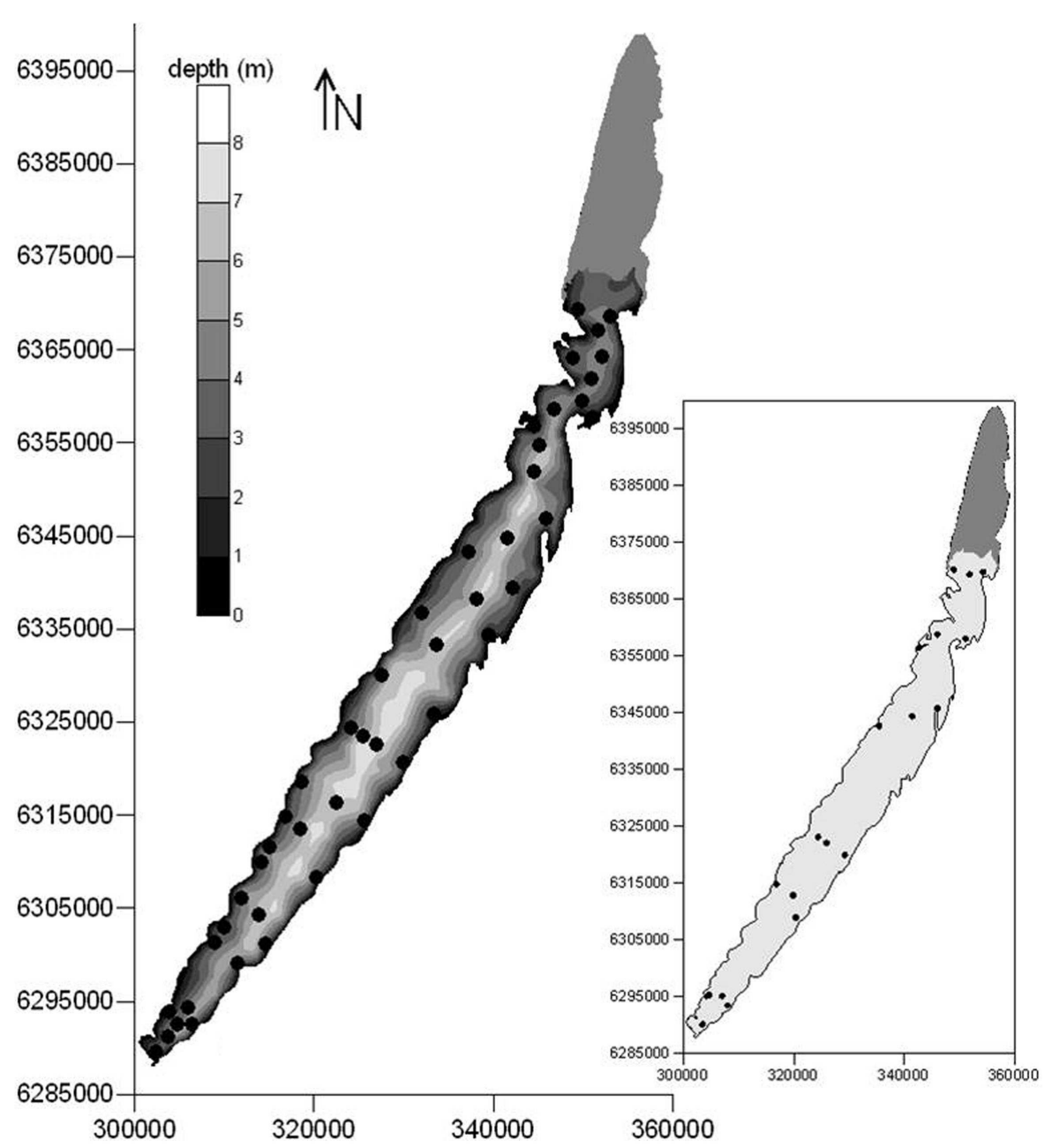

FIGURE 1 | Locations of sampling points for respiration rates sampled in March 2009 (main map), and extensive sampling campaigns of respiration rates and limnological variables carried out in 2010-2011 (inset) in Lake Mangueira, a large shallow lake in subtropical southern Brazil. Maps are georeferenced in UTM coordinate system. 
teflon-lined screw caps) were carefully filled with no headspace (Farjalla et al., 2001) and incubated at room temperature $\left(\sim 20^{\circ} \mathrm{C}\right)$ in the dark. DIC was analyzed in a Total Organic Carbon (TOC) Analyzer (Shimadzu VCPH). Bulk respiration rates were considered an approximation of bacterial respiration, since several pilot experiments with different water fractions showed no significant differences between the bulk and bacterial fractions after filtration in MN 640d Macherey-Nagel paper filters (2.0-4.0 $\mu \mathrm{m}$ mean retention size). This filtration has been extensively tested and successfully excludes ciliates, metazoans, and most flagellates.

\section{RESPIRATION IN LITTORAL x PELAGIC ZONES}

A large set of measurements of respiration rates, covering the entire Lake Mangueira, was taken in March 2009. The water was collected in the littoral and pelagic zones (littoral $n=21$; pelagic $n=26$ ) and the water was incubated in dark bottles, for 6 days in the laboratory (Wetzel and Likens, 2000). Dissolved oxygen was measured by a TOGA/SRI gas chromatograph (purge trap injector for water samples and TCD/HID detectors). Oxygen measurements were converted to carbon, assuming a molar conversion factor of 1.0 (del Giorgio et al., 1997). Results were expressed in $\mu \mathrm{g} \mathrm{C} \mathrm{L}^{-1} \mathrm{~h}^{-1}$, assuming a constant respiratory rate.

Nineteen points in the littoral and pelagic zones (littoral $n=12$; pelagic $n=7$ ) covering the entire lake were collected for several limnological variables during seven campaigns: $\mathrm{pH}, \mathrm{Abs} 250$, Abs365, Abs250:365, total phosphorus (TP), total nitrogen (TN), chlorophyll $a$, DOC, DIC, $\mathrm{O}_{2}$ consumption, $\mathrm{CO}_{2}$ accumulation, $p \mathrm{CO}_{2}$ in the water, and $\mathrm{CO}_{2}$ fluxes $\left(f \mathrm{CO}_{2}\right)$. With the exceptions of $p \mathrm{CO}_{2}$ and $\mathrm{CO}_{2}$ fluxes, all variables were collected in May, August, and November 2010 and March, May, August, and November 2011. $p \mathrm{CO}_{2}$ and $f \mathrm{CO}_{2}$ were estimated in February, May, August, and November 2010 and March, June, and August 2011.

Surface water was taken using a horizontal sampling bottle. $\mathrm{pH}$ was measured with a potentiometer (Wetzel and Likens, 2000). Abs250 and Abs365 refer to absorbance at 250 and $365 \mathrm{~nm}$ respectively, in $1 \mathrm{~cm}$-optical path length quartz cuvettes. The former is proportional to the low-molecular-weight compounds, while the latter is proportional to the high-molecular-weight compounds present; and Abs250:365 is the ratio Abs250:Abs365 (Strome and Miller, 1978; Lindell et al., 1995). Samples for TN and TP were frozen in $1 \mathrm{~L}$ polyethylene bottles, and these nutrients were measured by colorimetry (Mackereth et al., 1989). Chlorophyll $a$ was quantified through cold ethanol extraction (Jespersen and Christoffersen, 1987). DOC and DIC samples were collected in $30 \mathrm{~mL}$ precombusted $\left(450^{\circ} \mathrm{C}\right.$ for $\left.1 \mathrm{~h}\right)$ amber glass bottles. DOC samples received a few drops of $\mathrm{H}_{3} \mathrm{PO}_{4}^{-3}$, and DIC and DOC were analyzed in the same TOC analyzer (Shimadzu VCPH).

Oxygen consumption and $\mathrm{CO}_{2}$ accumulation were determined by incubation in glass serum bottles. The bottles were kept inside a thermal box (approximately $23^{\circ} \mathrm{C}$ ) and taken to the laboratory, totaling $120 \mathrm{~h}$ of incubation. $\mathrm{O}_{2}$ was measured in a TOGA/SRI gas chromatograph, and $\mathrm{CO}_{2}$ indirectly from measurements of DIC and $\mathrm{pH}$ after correction of temperature and ionic strength (Stumm and Morgan, 1996). The measurements were made at the beginning and at the end of incubation. The ionic strength was estimated from the electrical conductivity of the water measured in the field, using the following conversion formula (Snoeyink and
Jenkins, 1980):

$I S \approx 1.6 \times 10^{-5} \times$ Conductivity

where IS is the ionic strength and the water conductivity is measured in $\mu \mathrm{S} \mathrm{cm}^{-1}$.

The $p \mathrm{CO}_{2}$ in the water was calculated based on the Law of Henry, with the following equation:

$p C O_{2}^{w}=\frac{\alpha_{0} D I C}{K_{H}}$

where $\alpha_{0}$ corresponds to the fraction of DIC as $\mathrm{CO}_{2}$ and $K_{H}$ is the dissolution constant of $\mathrm{CO}_{2}$ expressed in moles $\mathrm{L}^{-1} \mathrm{~atm}^{-1}$ corrected for temperature in kelvin $\left(T_{k}\right)$ after the equation of Weiss (1974):

$\ln K_{H}\left(C O_{2}\right)=-58.0931+90.5069\left(\frac{100}{T_{k}}\right)+22.294 \ln \left(\frac{T_{k}}{100}\right)$

The flux of $\mathrm{CO}_{2}\left(f \mathrm{CO}_{2}\right.$, mmoles $\left.\mathrm{C} \mathrm{m}^{-2} \mathrm{~d}^{-1}\right)$ between atmosphere and lake was estimated with the following equation (MacIntyre et al., 1995):

$f C \mathrm{O}_{2}=k_{x}\left(p C \mathrm{O}_{2}^{a t m}-p C O_{2}^{w}\right)$

where $p \mathrm{CO}_{2}^{a t m}$ is the partial pressure of $\mathrm{CO}_{2}$ in the atmosphere (for $380 \mathrm{ppm}), \mathrm{pCO}_{2}^{w}$ is the partial pressure of $\mathrm{CO}_{2}$ estimated for the surface layer of the lake, and $k_{x}$ is the coefficient of mass transfer $\left(\mathrm{cm} \mathrm{h}^{-1}\right)$, given by the following empirical relationship:

$k_{x}=k_{600}\left(\frac{S_{c}}{600}\right)^{-x}$

where $x$ is equal to 0.66 for winds $<3.0 \mathrm{~m} \mathrm{~s}^{-1}$ and equal to 0.5 for winds $>3.0 \mathrm{~m} \mathrm{~s}^{-1}, S_{c}$ is the number of Schmidt for $\mathrm{CO}_{2}$, which is dependent on temperature $\left({ }^{\circ} \mathrm{C}\right)$, according to the following relationship (Wanninkhof, 1992):

$S_{c}\left(C_{2}\right)=1911.1-118.11 T+3.4527 T^{2}-0.04132 T^{3}$

where $k_{600}$ is estimated from wind velocity (Cole and Caraco, 1998):

$k_{600}=2.07+\left(0.215 U_{10}^{1.7}\right)$

where $U_{10}$ is the wind velocity $\left(\mathrm{m} \mathrm{s}^{-1}\right)$.

Data from the Santa Vitória do Palmar meteorological station (www.inmet.gov.br), located $7.0 \mathrm{~km}$ from the lake, were used to obtain air temperature and wind velocity.

\section{STATISTICAL TREATMENT}

Differences between DIC accumulation in dark (littoral) and clear (pelagic) water samples and among different time periods for each type of water were tested with one-way non-parametric ANOVA (NPMANOVA in the univariate mode) test (Anderson, 2001). The dissimilarity measure used was Euclidean distance, with 9999 permutations. Software: PAST 2.14 (Hammer et al., 2001). 
For the respiration data set, the mean rates of respiration in the littoral $(n=21)$ and pelagic zones $(n=26)$ were tested for difference with ANOVA after natural-log transformation (correction for normality). The association between rates of respiration (also transformed) of the cloud of points and the distances from the nearest margin was tested by linear regression (Software R 2.15.0, R Development Core Team, 2012).

The data from the $\mathrm{O}_{2}$ consumption, $\mathrm{CO}_{2}$ accumulation, $p \mathrm{CO}_{2}$, $\mathrm{CO}_{2}$ fluxes, and limnological variables obtained in the seven sampling campaigns were $z$-score standardized within each month and split into two categories, based on the distance from the nearest shore: littoral $(<1000 \mathrm{~m})$ and pelagic $(\geq 1000 \mathrm{~m})$. This threshold was based on the mean distance of the samples from the shore. Differences between the littoral and pelagic zones were tested for each variable individually ( $\mathrm{pH}, \mathrm{Abs} 250, \mathrm{Abs} 365, \mathrm{Abs} 250: 365, \mathrm{TP}, \mathrm{TN}$, chl $a, \mathrm{DOC}, \mathrm{O}_{2}, \mathrm{CO}_{2}, f \mathrm{CO}_{2}$ ) by one-way NPMANOVA (Anderson, 2001). We used the software PAST v. 2.14 (Hammer et al., 2001) with Euclidean distance and 9999 permutations. A posteriori contrast tests used Bonferroni correction $(n \times p$, where $n$ is the number of comparisons and $p$ is the $p$ value obtained by permutation) implemented in the software PAST 2.14 (Hammer et al., 2001).

The explanatory power of abiotic variables ( $\mathrm{pH}, \mathrm{Abs} 250$, Abs365, Abs250:365, TP, TN, chl $a$, and DOC) on $\mathrm{O}_{2}$ consumption, $\mathrm{CO}_{2}$ accumulation, $p \mathrm{CO}_{2}$, and $f \mathrm{CO}_{2}$ was assessed by binary recursive partitioning (regression tree) with the help of the R 2.15.0 (R Development Core Team, 2012) package \{rpart\} (Therneau et al., 2012) and following Crawley (2007). For $\mathrm{O}_{2}$ consumption and $\mathrm{CO}_{2}$ accumulation all months were included $(n=133)$; for $\mathrm{CO}_{2}$ and $f \mathrm{CO}_{2}$, given the unbalance in sampling months, February (2010) and June (2011) were excluded $(n=95)$.

\section{RESULTS}

\section{DIC ACCUMULATION EXPERIMENT}

The NPMANOVA test indicated that DIC was higher in the pelagic zone $\left(23.24 \pm 1.54 \mathrm{mg} \mathrm{CL}^{-1}\right)$ than in the littoral zone $\left(16.82 \pm 1.72 \mathrm{mg} \mathrm{C} \mathrm{L}^{-1}\right)$, pseudo- $F=163.0, p=0.0001$. There was no change in DIC with time: Littoral zone: pseudo- $F=0.957$, $p=0.524$; pelagic zone: $p$ seudo- $F=0.685, p=0.777$.

\section{RESPIRATION CLOUDS OF POINTS}

The respiration data collected from the entire lake revealed that respiration rates were significantly lower in the littoral zone: $F(1,45)=10.778, p<0.002$ (Figure 2A). The regression between respiration rates and distance from the nearest shore was marginally significant: $\ln ($ Respiration $)=-2.648+0.559[\ln ($ Distance $)]$, Adjusted $R^{2}=0.046, p=0.079$ (Figure 2B).

The NPMANOVA with all months revealed a significantly higher Abs250:365 in the littoral zone and a significantly higher TP and chl $a$ in the pelagic zone. DOC was marginally significantly higher in the pelagic zone (Tables 1 and 2).

The NPMANOVA by each month separately revealed that TP and chl $a$ were frequently higher in the pelagic zones (May, August 2010 and March, August, and November 2011). Less frequent, but also consistent was higher Abs250 and Abs250:365 in littoral zones (May 2010 and May and August 2011). Punctually, littoral zones

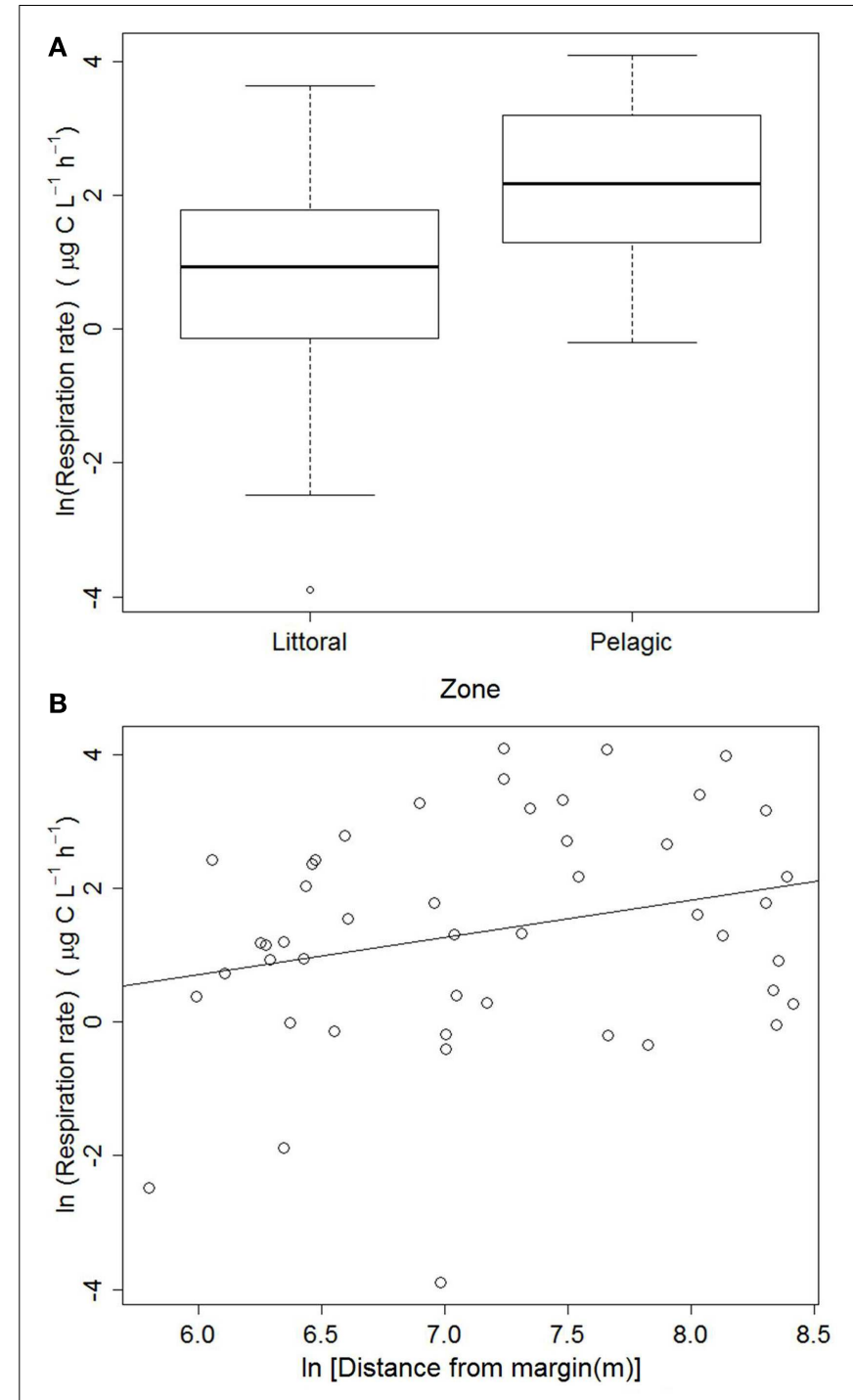

FIGURE 2 | Respiration rates in littoral $(n=21)$ and pelagic $(n=26)$ zones $(A)$ and regression of respiration rates against the distance to the nearest shore (B) in Lake Mangueira, sampled in March 2009.

also showed higher $\mathrm{pH}$ (May 2010) and DIC (August 2011), while the pelagic zone showed higher $\mathrm{CO}_{2}$ concentration (November 2010; Tables 1 and 2).

The regression trees revealed that the Abs250 was the major environmental variable influencing $\mathrm{O}_{2}$ consumption, $\mathrm{CO}_{2}$ production, and $p \mathrm{CO}_{2}$, while DOC influenced most the $f \mathrm{CO}_{2}$ (Figures 3A,B).

For $\mathrm{O}_{2}$ consumption, the highest mean occurred at Abs $250<0.064$; at Abs $250 \geq 0.064$, there was also influence of Abs365, chl $a$, DOC, and $\mathrm{pH}$, with high $\mathrm{O}_{2}$ consumption occurring at $\mathrm{Abs} 365 \geq 0.017$ and $\mathrm{DOC} \geq 2.54 \mathrm{mg} \mathrm{L}^{-1}$. At lower concentrations of DOC $\left(<2.54 \mathrm{mg} \mathrm{L}^{-1}\right), \mathrm{O}_{2}$ consumption was also high when the $\mathrm{pH}$ was $\geq 8.2$. Lowest $\mathrm{O}_{2}$ consumption occurred at Abs $365<0.017$ and chl a concentrations $\geq 4.02 \mu \mathrm{g} \mathrm{L}^{-1}$ (Figure 3A). 


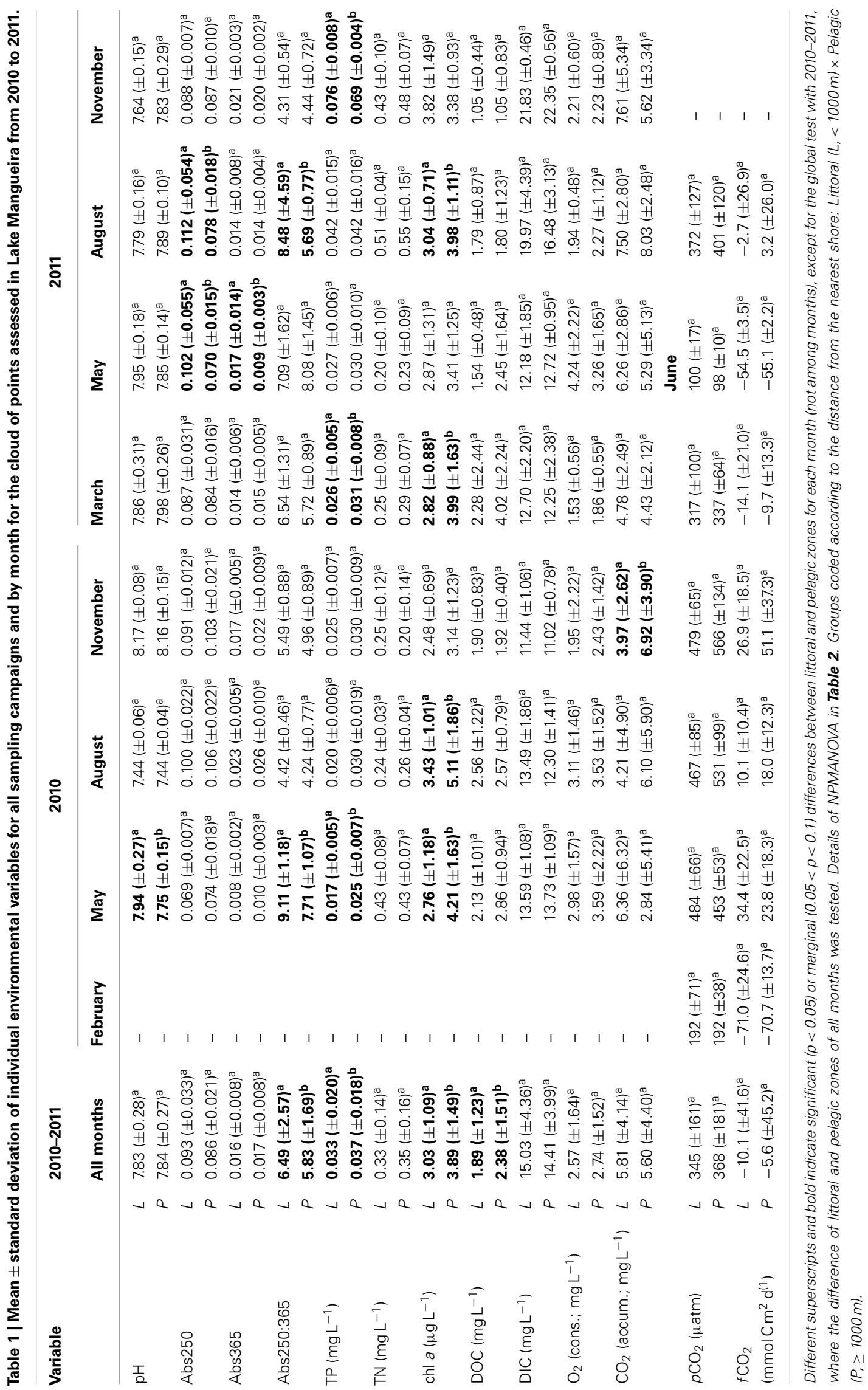


Table 2 | Non-parametric MANOVA (NPMANOVA) analysis on individual environmental variables for all campaigns and by month for the cloud of points sampled in lake Mangueria from 2010 to 2011.

\begin{tabular}{|c|c|c|c|c|}
\hline \multirow[t]{2}{*}{ Year } & \multirow[t]{2}{*}{ Month } & \multirow[t]{2}{*}{ Variable } & \multicolumn{2}{|l|}{ NPMANOVA } \\
\hline & & & Output & Effect \\
\hline \multirow[t]{4}{*}{ 2010-2011 } & All & Abs250:365 & $F^{*}=5.20, p=0.023$ & $L>P$ \\
\hline & & TP & $F^{*}=4.02, p=0.044$ & $P>L$ \\
\hline & & Chl a & $F^{*}=12.44, p<0.001$ & $P>L$ \\
\hline & & DOC & $F^{*}=3.11, p=0.083^{*}$ & $P>L$ \\
\hline \multirow[t]{6}{*}{2010} & May & $\mathrm{pH}$ & $F^{*}=3.95, p=0.066^{*}$ & $L>P$ \\
\hline & & Abs250:365 & $F^{*}=7.02, p=0.0172$ & $L>P$ \\
\hline & & TP & $F^{*}=9.24, p=0.010$ & $P>L$ \\
\hline & & Chl a & $F^{*}=4.15, p=0.062^{*}$ & $P>L$ \\
\hline & August & Chl a & $F^{*}=4.78, p=0.042$ & $P>L$ \\
\hline & November & $\mathrm{CO}_{2}$ & $F^{*}=3.14, p=0.093^{*}$ & $P>L$ \\
\hline \multirow[t]{8}{*}{2011} & March & $\mathrm{TP}$ & $F^{*}=2.91, p=0.098^{*}$ & $P>L$ \\
\hline & & Chl a & $F^{*}=3.06, p=0.090^{*}$ & $P>L$ \\
\hline & May & Abs250 & $F^{*}=3.67, p=0.042$ & $L>P$ \\
\hline & & Abs365 & $F^{*}=3.29, p=0.044$ & $L>P$ \\
\hline & August & Abs 250 & $F^{*}=4.03, p=0.045$ & $L>P$ \\
\hline & & Abs250:365 & $F^{*}=4.41, p=0.013$ & $L>P$ \\
\hline & & Chl a & $F^{*}=3.97, p=0.0597^{*}$ & $P>L$ \\
\hline & November & TP & $F^{*}=7.14, p=0.015$ & $L>P$ \\
\hline
\end{tabular}

Groups coded according to the distance from the nearest shore: littoral $(L,<1000 \mathrm{~m}) \times$ Pelagic $(P, \times \geq 1000 \mathrm{~m})$. In bold: $\left.p<0.05 ;{ }^{*}, 0.05<p<0.1\right) . F^{*}$, pseudo-F.

$\mathrm{CO}_{2}$ production was also high at Abs $250<0.064$, but reached higher means at Abs250 $\geq 0.064)$, Abs250:365<7.35, DOC $<2.51 \mathrm{mgL}^{-1}, \mathrm{pH} \geq 7.67$, and high chl a concentrations (between 2.59 and $3.07 \mu \mathrm{gL}^{-1}$ ). At DOC concentrations $<2.51 \mathrm{mgL}^{-1}$ and low $\mathrm{pH}<7.67$, the mean was also high. The low values, however, occurred at Abs $250 \geq 0.064$, and Abs250:365 $\geq 7.35$ (Figure 3B).

$p \mathrm{CO}_{2}$ showed high values at Abs $250 \geq 0.104$. At lower Abs 250 $(<0.104)$, there was also influence of DOC, TP, pH, and Abs250, with lowest values occurring at DOC between 0.58 and $3.95 \mathrm{mg} \mathrm{L}^{-1}, \mathrm{TP} \geq 0.029 \mathrm{mg} \mathrm{L}^{-1}$, and $\mathrm{pH} \geq 7.70$ (Figure 4A).

$\mathrm{fCO}_{2}$ showed a strong relationship with DOC concentrations. At DOC $\geq 2.54 \mathrm{mg} \mathrm{L}^{-1}$, and Abs $250 \geq 0.0853$ it was found the highest positive value of $\mathrm{fCO}_{2}$. A negative mean was found with values of DOC between 1.48 and $2.54 \mathrm{mg} \mathrm{L}^{-1}$ and at Abs250 $\geq 0.0846$ (Figure 4B).

\section{DISCUSSION}

Our results showed that respiration can be lower in the littoral zone, based on the consistently lower DIC in water collected from this zone in incubation assays. In the first whole-lake survey, we found significantly lower respiration rates in these zones and a marginal $(p=0.079)$ increase of respiration rate with distance to the nearest shore. In the extensive sampling, this was not consistently found throughout all months. Marginally $(p=0.093)$ lower $\mathrm{CO}_{2}$ accumulation was detectable in at least 1 month (November 2010) in the littoral zones. However, significantly higher DIC

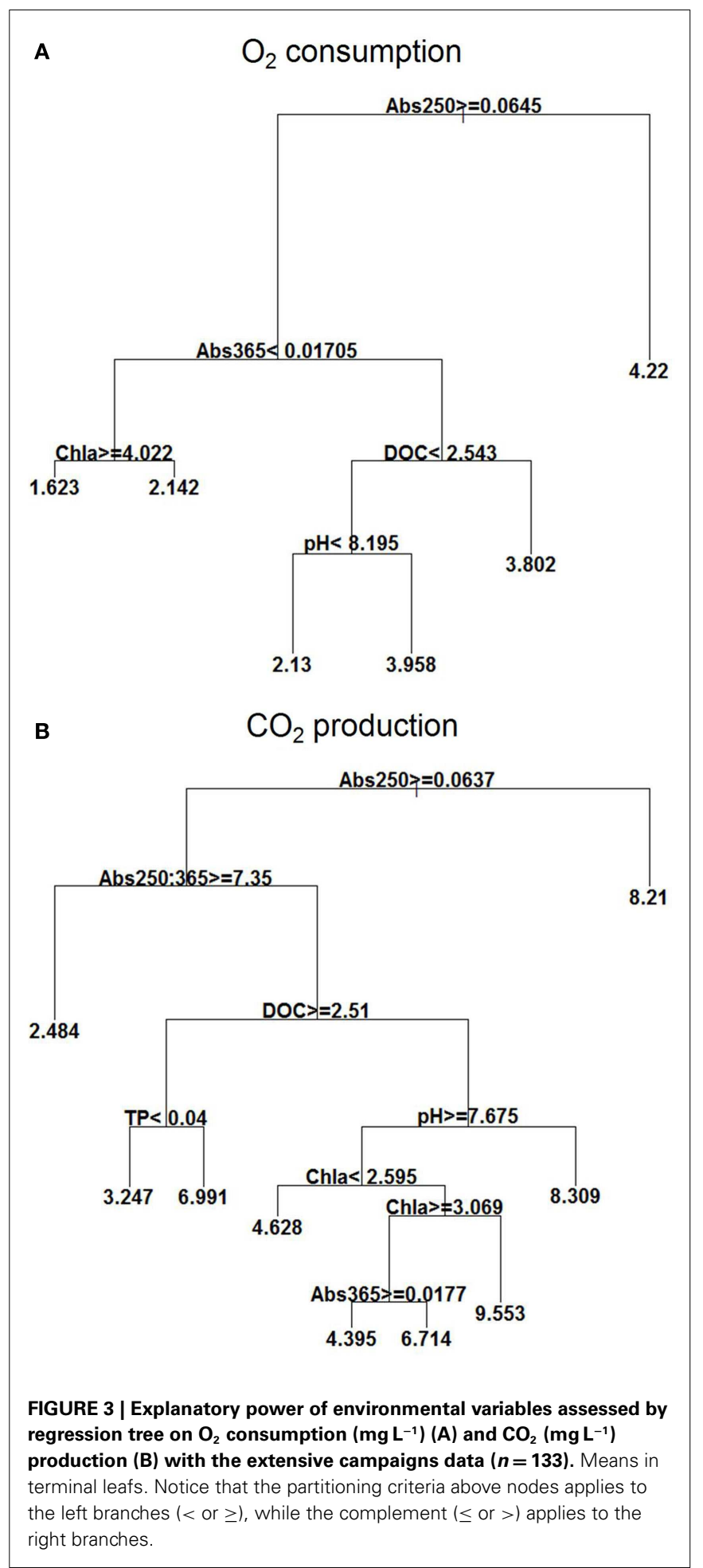

occurred in the littoral zones in August 2011. These differences are possibly associated with differences in environmental conditions between these zones, as shown by consistently higher chlorophyll $a$ and TP, marginally higher DOC $(p=0.083)$ and significantly lower Abs250:365 in the pelagic zone, as shown by NPMANOVA analyses on the entire data set (all months). The regression tree analyses 


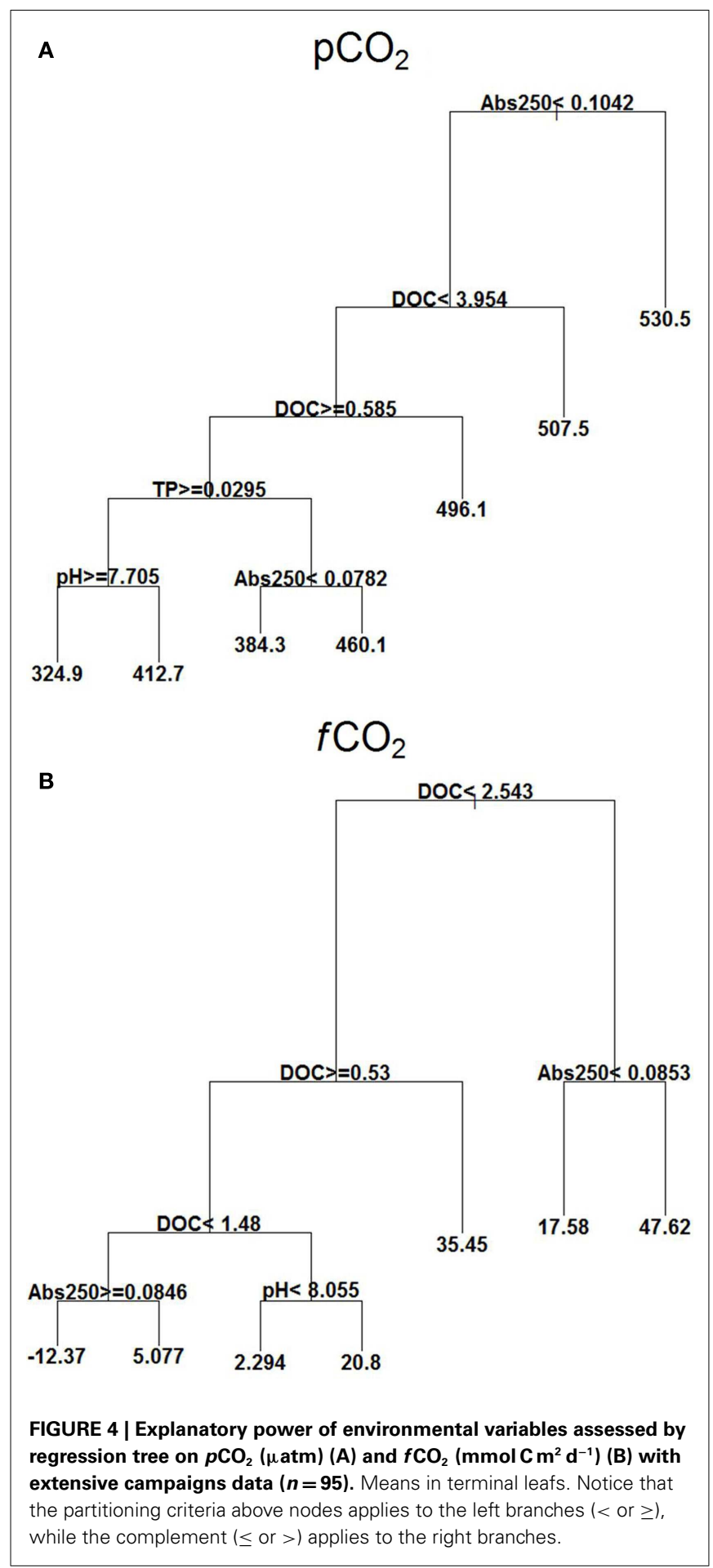

confirmed that higher $\mathrm{O}_{2}$ consumption and $\mathrm{CO}_{2}$ production are associated to low Abs250, high DOC, and high Abs365. $p \mathrm{CO}_{2}$ and $\mathrm{fCO}_{2}$, at their turn, were higher at high Abs250, DOC, and TP.

Our results showed contrasting patterns. The DIC accumulation experiment and the extensive sampling of 2009 supported our hypothesis that respiration is lower in the littoral zone than in the pelagic zone. However, apart from the marginally higher $\mathrm{CO}_{2}$ accumulation in November 2010 in the pelagic zone, the extensive sampling of 2010-2011 did not show such striking evidence in support of the hypothesis. This could be due to the smaller number of points sampled, but also the result of intensive mixing of Lake Mangueira by wind (Cardoso et al., 2012), which makes it difficult to detect abrupt differences in respiration in the field, as indicated by several marginal relationships found. This could have been crucial because of the smaller set of sampling points.

One hypothesis for the lack of detection of DIC accumulation is that in areas with an extensive coverage of macrophytes, like southern Mangueira, the macrophyte influence might reach pelagic zones as well. We unfortunately do not have enough data gathered yet to envisage how, why, and when this occurs. We nevertheless did observe that DIC was on average higher in the pelagic zone, likely due to very low accumulation rates (not statistically significant in $<14$ days). When we extend our perspective (spatially and temporally) to the whole lake and for different years and seasons, we see a different picture, where we do detect respiration (even though still low) enough to put in evidence differences between littoral and pelagic zones. Another important point to take into consideration is that lake Mangueira is of marine origin (former closed estuary) with significant accumulation of sea shell banks. This explains the high background levels of DIC in the lake, and could have masked measurements of bacterial respiration based on DIC. This also suggests that it is not the best method for this purpose, and may have been the cause for the disagreement between the patterns of DIC and $\mathrm{O}_{2} / \mathrm{CO}_{2}$ respiration rates observed.

As stated, in Lake Mangueira, rates of respiration are extremely low, and it is striking that it is impossible to detect respiration in dark bottles over a period shorter than 5 days. The mean respiration rates in the littoral $(1.34 \mathrm{mmol}$ $\left.\mathrm{O}_{2} \mathrm{~m}^{-3} \mathrm{~h}^{-1}\right)$ and pelagic zones $\left(1.43 \mathrm{mmol} \mathrm{O}_{2} \mathrm{~m}^{-3} \mathrm{~h}^{-1}\right)$ are closer to the lower range presented in the extensive compilation of plankton respiration rates $\left(0.029\right.$ to $\left.6.73 \mathrm{mmol} \mathrm{O}_{2} \mathrm{~m}^{-3} \mathrm{~h}^{-1}\right)$ by Pace and Prairie (2005). This is also confirmed in a carbon-basis comparison, as the rates of respiration in this study (Littoral zone: Mean: $1.469 \mu \mathrm{g} \mathrm{C} \mathrm{L}^{-1} \mathrm{~h}^{-1}$, range: 0.008 $6.241 \mu \mathrm{gCL}^{-1} \mathrm{~h}^{-1}$; Pelagic zone: Mean: $6.540 \mu \mathrm{gCL}^{-1} \mathrm{~h}^{-1}$, range: $0.250-23.718 \mu \mathrm{g} \mathrm{C} \mathrm{L}^{-1} \mathrm{~h}^{-1}$ ) are also close to the lower range reported in other systems: Delaware Bay and salt marshes (range: 2.53-13.14 $\mu \mathrm{g} \mathrm{C} \mathrm{L}^{-1} \mathrm{~h}^{-1}$; del Giorgio and Newell, 2012) and 20 Quebec lakes (range: $0.168-2.138 \mu \mathrm{g} \mathrm{C} \mathrm{L}^{-1} \mathrm{~h}^{-1}$ ).

The differences in respiration in the littoral and pelagic zones of Lake Mangueira may reflect differences in the responses of bacterial metabolism to the following drivers: (I) quantity and bioavailability of DOC; and (II) phosphorus limitation. Our results supported both hypotheses, as indicated by the lower chl $a$, DOC, and TP, and the higher proportion of low-molecular-weight compounds (in terms of Abs250 and Abs250:365) in the littoral zone found in many cases.

The generally low DOC bioavailability in the form of humic substances (Münster and Chróst, 1990) indicates that a large proportion of dissolved carbon in Lake Mangueira is refractory to bacterial consumption. When compared to the values reported by Amado et al. (2006) for an Amazonian river and a stream, the content of humic substances in Lake Mangueira is 6 times higher. The humic content is at least 4 times higher than for values reported for the mesohumic Lake Sjättesjön (Lindell et al., 1995), or even as much as 12-17 times higher than reported for the Gutierrez River 
(all comparisons on the basis of the Abs250:365 nm ratio; Pérez et al., 2003).

DOC is generally high in densely vegetated areas (Wetzel, 1992; Reitner et al., 1999); however, we found higher DOC in the pelagic zone, along with chl $a$, suggesting the importance of algal carbon to the system. This is in accordance with the long-recognized bacterial dependence on algal production (Cole, 1982), particularly because the more labile algal DOC sustains higher bacterial growth efficiency (Kritzberg et al., 2005). This was evident by the greater phytoplankton biomass concentrated (higher chlorophyll $a$ ) in the pelagic zone at the end of winter (August 2010), which was respired by bacteria with the rising temperatures in spring (highest $\mathrm{CO}_{2}$ accumulation found in November 2010; Table 1).

The higher concentration of low-molecular-weight substrates in the littoral zone can also imply less availability of substrates (Amon and Benner, 1996). Contrariwise, these substrates are supposedly more easily taken up by bacteria, but they may be more refractory to consumption. Tranvik (1990) found higher bacterial production per unit of carbon in high-molecular-weight DOC than in low-molecular-weight DOC in lakes with different humic content in Sweden. In another study, Amon and Benner (1996) found higher bacterial production and respiration in highmolecular-weight (HMW, >1 KDa) than low-molecular-weight (LMW, $<1 \mathrm{KDa}$ ) DOC. Based on these results, the authors proposed the size-reactivity continuum model, which predicts that the major path of degradation goes from large, highly reactive to small, highly recalcitrant molecules. If this hypothesis is broadly applicable to many ecosystems, it suggests that in Lake Mangueira the compounds lixiviated by the macrophytes may undergo some degradation, but accumulate as dissolved, unreactive LMW compounds with very low degradation rates in the littoral zones, in agreement with the higher Abs250:365 and lack of change in the DIC with time in the incubation experiment. Our results strongly support this hypothesis, as higher $\mathrm{O}_{2}$ consumption, and $\mathrm{CO}_{2}$ production were found for low Abs250 and high Abs365 or conversely lower $\mathrm{O}_{2}$ consumption, and $\mathrm{CO}_{2}$ production were found when the ratio Abs250:365 was too high.

The lower TP found in the littoral zone can be attributed to the generally low watershed load and also the great competitive advantage of macrophytes in taking up this nutrient. As noted by Vidal et al. (2011), not only carbon, but the carbon: phosphorus ratio controls bacterial production and respiration in lakes, and even a situation of labile DOC accumulation can occur under phosphorus limitation (Vadstein et al., 2003). In fact, increased bacterial density in the presence of macrophytes after phosphorus amendment has been described (Huss and Wehr, 2004; Joniak et al., 2007; Morozova et al., 2011). An interesting result was the lower TP in the pelagic zone in November 2011, which could be due to depletion of this nutrient in the pelagic zone during summer (Table 1); however, no similar depletion occurred in 2010, and cannot be assumed as a pattern based on our data. The regression trees indicated an effect of TP when DOC is high; low TP is associated to low $\mathrm{CO}_{2}$ production, while the opposite situation also applies, supporting the hypothesis that low respiration can be associated to low TP. This is expected to generate lower $p \mathrm{CO}_{2}$ in littoral zones where TP is lower; however a difference in $p \mathrm{CO}_{2}$ between littoral and pelagic zones was not detected. The regression tree revealed that $p \mathrm{CO}_{2}$ was low when TP was high in samples of high DOC. This is in agreement with low phosphorus leading to $\mathrm{CO}_{2}$ supersaturation in order to balance this nutrient deficiency (Hessen, 1992), and suggests that this also occurs in lake Mangueira. As $\mathrm{CO}_{2}$ concentration is only part of $p \mathrm{CO}_{2}$, other factors affecting $p \mathrm{CO}_{2}$ equilibrium need to be taken into account, and this may be the cause for the apparent contradiction between $\mathrm{CO}_{2}$ production and $p \mathrm{CO}_{2}$ predicted from TP.

Levels of $p \mathrm{CO}_{2}$ were in general lower than in other lakes with similar or even lower TP content: mean around $660 \mu$ atm (range: 130-1010 $\mu \mathrm{atm}$ ) for a range of Quebec lakes with variable trophic content; mean around $1036 \mu$ atm (range: 1-20 $249 \mu \mathrm{atm}$ ) for a comprehensive compilation of data for 1835 lakes distributed worldwide (Cole et al., 1994). These levels are far above those found in this study. This could be explained by the generally low DOC concentration in Lake Mangueira (mean around $2.2 \mathrm{mg} \mathrm{L}^{-1}$ ), because it has been demonstrated that lakes are net heterotrophic (supersaturated with $\mathrm{CO}_{2}$ ) above concentrations of 4-6 mg L ${ }^{-1}$ DOC (Prairie et al., 2002). This contrasts with the generally accepted view that most aquatic systems are net heterotrophic and function as net sources of $\mathrm{CO}_{2}$ to the atmosphere (Cole et al., 1994; Duarte and Prairie, 2005), which makes Lake Mangueira (particularly the littoral zone) an exception to this general rule.

The analysis of the frequency of occurrence (histogram) of classes of $f \mathrm{CO}_{2}$ between the lake surface and atmosphere in the littoral zone showed a higher frequency of positive (net influx of $\mathrm{CO}_{2}$ to the lake), while the pelagic zone showed a higher frequency of negative values (net efflux of $\mathrm{CO}_{2}$ from the lake) of $f \mathrm{CO}_{2}$, even though there was no difference between the means in the littoral and pelagic zones. A closer inspection of the fluxes showed that they are very close to zero, and the lake functions as a sink of $\mathrm{CO}_{2}$, especially during winter and spring (May to November), when the $\mathrm{CCO}_{2}$ becomes close to zero or even positive (Figure 5). The regression tree showed that high, positive $\mathrm{fCO}_{2}$ was associated to higher DOC and Abs250, contrary to the expectation that higher DOC is associated to higher $\mathrm{CO}_{2}$ supersaturation and hence net efflux of $\mathrm{CO}_{2}$ from the lake; negative $\mathrm{fCO}_{2}$ was associated to intermediate values of DOC and high Abs250. However, more direct evidence needs to be gathered in order to draw more solid associations.

Besides main effects of DOC and nutrients, other possible explanations for low respiration in the littoral zone in Lake Mangueira have also been hypothesized: formation of hydrogen peroxide by UV radiation, release of allelochemicals by macrophytes, and limitation by micronutrients, e.g., iron and silicate. UV exposure of macrophytes products of degradation in Lake Mangueira has been demonstrated to decrease bacterial production, possibly by formation of $\mathrm{H}_{2} \mathrm{O}_{2}$ (They et al., submitted). The release of allelopathic substances by (mainly submersed) macrophytes is widely known (Gross et al., 2007; Mulderij et al., 2007), and has been considered as a possible explanation for lower bacterial diversity (Wu et al., 2007) and metabolism (They et al., 2010 ) in areas extensively colonized by macrophytes. We have data on $\mathrm{Fe}$ and silicate from the extensive campaigns that were not included in the results because they are out of objectives of this 


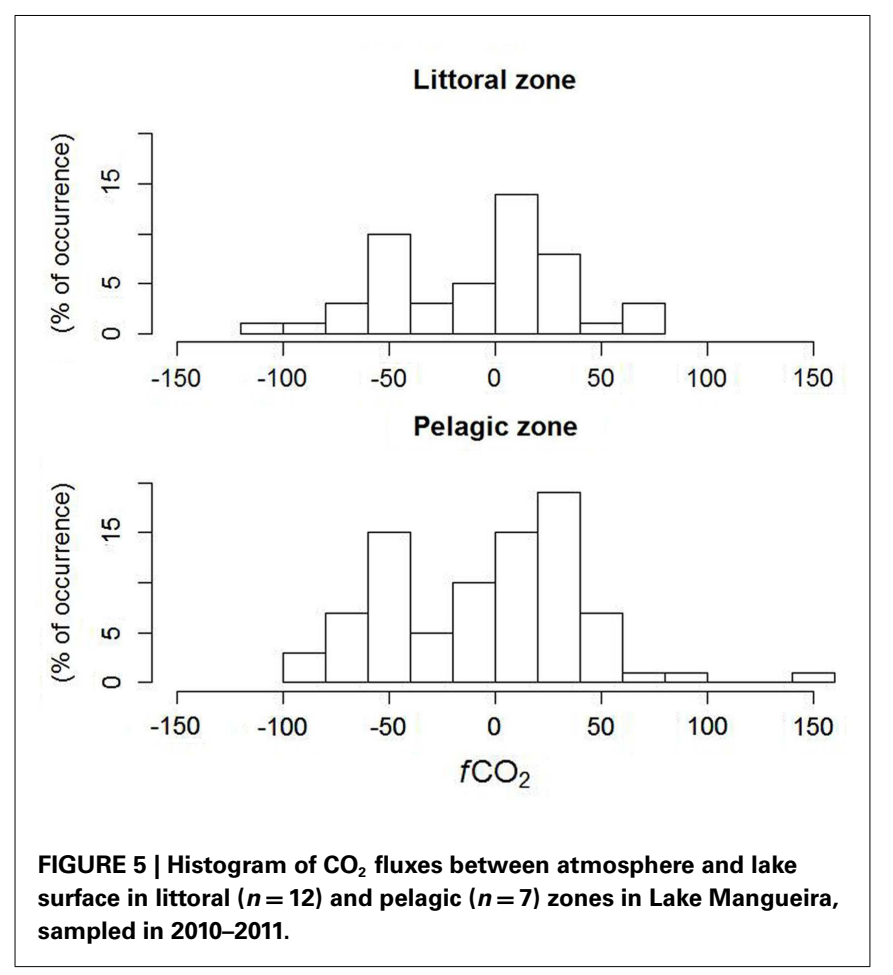

study. Based on these data, there is no evidence of iron limitation, since the values found in the littoral zones $\left(0.325 \pm 0.253 \mathrm{mg} \mathrm{L}^{-1}\right)$ and pelagic zones $\left(0.349 \pm 0.248 \mathrm{mg} \mathrm{L}^{-1}\right)$ are far above concentrations reported to be limiting in other systems, like, e.g., open ocean $\left(<5.6 \times 10^{-6} \mathrm{mg} \mathrm{L}^{-1}\right.$; Oliver et al., 2004$)$ or lake Erie $\left(1.7 \times 10^{-4}\right.$ $1.09 \times 10^{-2} \mathrm{mg} \mathrm{L}^{-1}$; North et al., 2007). Silicate concentrations are far above those reported to be limiting $(2 \mu \mathrm{m})$ for diatoms (Egge and Aksnes, 1992) in littoral $(100.92 \pm 23.99 \mu \mathrm{m})$ and pelagic zones $(100.04 \pm 23.83 \mu \mathrm{m})$, and thus there no evidence of possible impacts on bacterial supply of organic substrates derived from silicate limitation of phytoplankton.

One important and final consideration is that we found support for our hypotheses by different, independent methods: one-time DIC accumulation, extensive one-time sampling and extensive many-times sampling by $\mathrm{O}_{2}$ consumption, and $\mathrm{CO}_{2}$ production measurements. Each method has its own limitations, as we

\section{REFERENCES}

Amado, A. M., Farjalla, V. F., Esteves, F. A., Bozelli, R. L., Roland, F., and Enrich-Prast, A. (2006). Complementary pathways of dissolved organic carbon removal pathways in clear-water Amazonian ecosystems: photochemical degradation and bacterial uptake. FEMS Microbiol. Ecol. 56, 8-17.

Amon, R. M. W., and Benner, R. (1996). Bacterial utilization of different size classes of dissolved organic matter. Limnol. Oceanogr. 41, 41-51.

Anderson, M. J. (2001). A new method for non-parametric multivariate analysis of variance. Austral Ecol. 26, 32-46.

believed was crucial in the DIC experiment; had we employed a longer incubation period, we could have seen some detectable accumulation. Differences between littoral and pelagic zones has long been recognized, but what is generally believed is that macrophyte presence/carbon is always good to bacteria, a paradigm our data do not support.

The littoral zone of Lake Mangueira (especially in the north and south) is extensively colonized by emergent and submersed macrophytes, respectively, and these plants are expected to contribute large amounts of organic carbon to the system. However, our results showed that respiration in this zone can be lower than in the pelagic zone, at least during a part of the year. This may be the result of differences in DOC quality, mainly derived from macrophytes in the littoral zone and phytoplankton in the pelagic zone. The disappearance of these differences may be due to seasonality or to masking by mixing in this shallow, winddominated lake. The finding of lower respiration rates in the littoral zone means that DOC remains in the system, mostly in a low-molecular-weight, unreactive form. Hence, the general belief that macrophyte-derived carbon is always beneficial to bacteria is not supported. The littoral zone, therefore, shows a greater tendency to be a $\mathrm{CO}_{2}$ sink, compared to the pelagic zone. If lower respiration in littoral zones is a common feature of subtropical shallow lakes dominated by macrophytes, there may be important and still unrecognized implications for their global carbon metabolism. However important these implications may seem, important issues (e.g., organic carbon molecular size and quality spectra, effect of taxonomic structure of macrophytes, bacterial taxonomic and functional diversity, the role of sediment bacteria, and more experimental and field evidence) need to be addressed for a better understanding of the many ways the interaction between macrophytes and bacteria can impact global carbon metabolism of lakes.

\section{ACKNOWLEDGMENTS}

The authors draw particular attention to the assistance provided by the Chico Mendes Institute of Biodiversity (ICM-Bio - ESEC TAIM). Financial support was provided by the Conselho Nacional de Desenvolvimento Científico e Tecnológico $(\mathrm{CNPq})$ under the Brazilian Network of Long-Term Ecological Research sites, Site 7, Sistema Hidrológico do Taim. We are also grateful to Dr. Janet W. Reid (JWR Associates) for revising the English text.

Cimbleris, A. C. P., and Kalff, J. (1998). Planktonic bacterial respiration as a function of C:N:P ratios across temperate lakes. Hydrobiologia 384 89-100.

Cole, J. J. (1982). Interactions between bacteria and algae in aquatic ecosystems. Annu. Rev. Ecol. Syst. 13, 291-314.

Cole, J. J., and Caraco, N. F. (1998). Atmospheric exchange of carbon dioxide in a low-wind oligotrophic lake measured by the addition of SF6. Limnol. Oceanogr. 43, 647-656.

Cole, J. J., Caraco, N. F., Kling, G. W., and Kratz, T. K. (1994). Carbon dioxide supersaturation in the surface waters of lakes. Science 265, 1568-1570.

Crawley, M. J. (2007). "Tree models," in The $R$ Book, ed. M. J. Crawley (West Sussex: Wiley \& Sons, Ltd), 685-700.

del Giorgio, P. A., Cole, J. J., and Cimbleris, A. (1997). Respiration rates in bacteria exceed phytoplankton production in unproductive aquatic systems. Nature 385, 101-108.

del Giorgio, P. A., and Newell, R. E. I. (2012). Phosphorus and DOC availability influence the partitioning between bacterioplankton production and respiration in tidal marsh ecosystems. Environ. Microbiol. 14, 1296-1307. 
Duarte, C. M., and Prairie, Y. T. (2005). Prevalence of heterotrophy and atmospheric $\mathrm{CO} 2$ emissions from aquatic ecosystems. Ecosystems 8, 862-870.

Egge, J. K., and Aksnes, D. L. (1992). Silicate as regulating nutrient in phytoplankton competition. Mar. Ecol. Prog. Ser. 83, 281-289.

Farjalla, V. F., Anesio, A. M., Bertilsson, S., and Granéli, W. (2001). Photochemical reactivity of aquatic macrophyte leachates: abiotic transformations and bacterial response. Aquat. Microb. Ecol. 24, 187-195.

Gross, E. M., Hilt née Körner, S., Lombardo, P., and Mulderij, G. (2007). Searching for allelopathic effects of submerged macrophytes on phytoplankton - state of the art and open questions. Hydrobiologia 584, 77-88.

Hammer, Ø., Harper, D. A. T., and Ryan, P. D. (2001). PAST: paleontological statistics software package education and data analysis. Palaeontol. Electronica 4, 9p.

Hessen, D. O. (1992). Dissolved organic carbon in a humic lake: effects on bacterial production and respiration. Hydrobiologia 229, 115-123.

Huss, A. A., and Wehr, J. D. (2004). Strong indirect effects of a submersed aquatic macrophyte, Vallisneria americana, on bacterioplankton densities in a mesotrophic lake. Microb. Ecol. 45, 305-315.

Jahnke, R. A., and Craven, D. B. (1995). Quantifying the role of heterotrophic bacteria in the carbon cycle: a need for respiration measurements. Limnol. Oceanogr. 40, 436-441.

Jespersen, A.-M., and Christoffersen, K. (1987). Measurements of chlorophyll-a from phytoplankton using ethanol as extraction solvent. Arch. Hydrobiol. 109, 445-454.

Joniak, T., Kuczynska-Kippen, N., and Nagengast, B. (2007). The role of aquatic macrophytes in microhabitatual transformation of physical-chemical features of small water bodies. Hydrobiologia 584, 101-109.

Kritzberg, E. S., Cole, J. J., Pace, M. M., and Granéli, W. (2005). Does autochthonous primary production drive variability in bacterial metabolism and growth efficiency in lakes dominated by terrestrial $\mathrm{C}$ inputs? Aquat. Microb. Ecol. 38, 103-111.

Lauster, G. H., Hanson, P. C., and Kratz, T. K. (2006). Gross primary production and respiration differences among littoral and pelagic habitats in northern Wisconsin lakes. Can. J. Fish. Aquat. Sci. 63, 1130-1141.

Lindell, M. J., Granéli, W., and Tranvik, L. J. (1995). Enhanced bacterial growth in response to photochemical transformation of dissolved organic matter. Limnol. Oceanogr. 40, 195-199.

MacIntyre, S., Wanninkhof, R., and Chanton, J. P. (1995). "Trace gas change across the air-water interface in freshwaters and coastal marine environments," in Biogenic Trace Gases: Measuring Emissions from Soil and Water, eds P. A. Matson and R. C. Harris (Oxford: Blackwell), 52-97.

Mackereth, F. J. H., Heron, J., and Talling, J. F. (1989). Water Analysis: Some Revised Methods for Limnologists, 2nd Edn. Kendal: Freshwater Biological Association.

Morozova, O. V., Ratushnyak, A. A., Tarasov, O. Y., and Trushin, M. V. (2011). The role of bacterioplankton and aquatic macrophytes in autopurification of hydroecosystems polluted with phosphorus. Middle East J. Sci. Res. 7, 346-351.

Mulderij, G., Van Nes, E. H., and Donk, E. V. (2007). Macrophytephytoplankton interactions: the relative importance of allelopathy versus other factors. Ecol. Model. 204, 85-92.

Münster, U., and Chróst, R. J. (1990). "Origin, composition, and microbial utilization of dissolved organic matter," in Aquatic Microbial Ecology, eds J. Overbeck and R. J. Chróst (New York: Springer-Verlag), 8-46.

North, R. L., Guildford, S. J., Smith, R. E. H., Havens, S. M., and Twiss, M. R. (2007). Evidence for phosphorus, nitrogen, and iron colimitation of phytoplankton communities in lake Erie. Limnol. Oceanogr. 52, 315-328.

Oliver, J. L., Barber, R. T., Smith, W. O. Jr., and Ducklow, H. W. (2004). The heterotrophic bacterial response during the Southern Ocean iron experiment (SOFex). Limnol. Oceanogr. 49, 2129-2140.

Pace, M. L., and Prairie, Y. T. (2005). "Respiration in lakes," in Respiration in Aquatic Ecosystems, eds P. A. del Giorgio and P. J. B. Williams (New York: Oxford University Press), 103-121.

Pérez, A. P., Diaz, M. M., Ferraro, M. A., Cusminsky, G. C., and Zagarese, H. E. (2003). Replicated mesocosm study on the role of natural ultraviolet radiation in high CDOM, shallow lakes. Photochem. Photobiol. Sci. 2, 118-123.
Prairie, Y. T., Bird, D. F., and Cole, J. J. (2002). The summer metabolic balance in the epilimnion of southeastern Quebec lakes. Limnol. Oceanogr. 47, 316-321.

R Development Core Team. (2012). R: A Language and Environment for Statistical Computing. Vienna: R Foundation for Statistical Computing. Available at: http://www.Rproject.org/

Reitner, B., Herzig, A., and Herndl, G. J. (1999). Dynamics in bacterioplankton production in a shallow, temperate lake (Lake Neusiedl, Austria): evidence for dependence on macrophyte production rather on phytoplankton. Aquat. Microb. Ecol. 19, 245-254.

Rooney, N., and Kalff, J. (2003). Interactions among epilimnetic phosphorus, phytoplankton biomass and bacterioplankton metabolism in lakes of varying submerged macrophyte coverage. Hydrobiologia 501, 75-81.

Smith, E. M., and Prairie, Y. T. (2004). Bacterial metabolism and growth efficiency in lakes: the importance of phosphorus availability. Limnol. Oceanogr. 49, 137-147.

Snoeyink, V. L., and Jenkins, D. (1980). Water Chemistry. New York: Wiley, 58-85.

Stanley, E. H., Johnson, M. D., and Ward, A. K. (2003). Evaluating the influence of macrophytes on alga and bacterial production in multiple habitats of a freshwater wetland. Limnol. Oceanogr. 48, 1101-1111.

Strome, D. J., and Miller, M. C. (1978). Photolytic changes in dissolved humic substances. Verh. Int Ver. Theor. Angew. Limnol. 20, 1248-1254.

Stumm, W., and Morgan, J. J. (1996). Aquatic Chemistry: Chemical Equilibria and Rates in Natural Waters. New York: John Wiley \& Sons, 1022.

Therneau, T., Atkinson, B., Ripley, B. (2012). rpart: Recursive Partitioning. $R$ Package Version 3.155. Available at: http://CRAN.Rproject.org $/$ package $=$ rpart

They, N. H., Marques, D. M., Jeppesen, E., and Søndergaard, M. (2010). Bacterioplankton in the littoral and pelagic zones of subtropical shallow lakes. Hydrobiologia 646, 311-326.

Tranvik, L. J. (1990). Bacterioplankton growth on fractions of dissolved organic carbon of different molecular weights from humic and clear waters. Appl. Environ. Microbiol. 56, 1672-1677.

Vadstein, O., Olsen, L. M., Busch, A., Andersen, T., and Reinertsen, $\mathrm{H}$.
R. (2003). Is phosphorus limitation of planktonic heterotrophic bacteria and accumulation of degradable DOC a normal phenomenon in phosphorus-limited system? A microcosm study. FEMS Microbiol. Ecol. 46, 307-316.

Vidal, L. O., Granéli, W., Daniel, C. B., Heiberg, L., and Roland, F. (2011). Carbon and phosphorus regulating bacterial metabolism in oligotrophic boreal lakes. J. Plankton Res. 33, 1747-1756.

Wanninkhof, R. (1992). Relationship between wind-speed and gas exchange over the ocean. J. Geophys. Res. 97, 7373-7382.

Weiss, R. F. (1974). Carbon dioxide in water and seawater; the solubility of a non-ideal gas. Mar. Chem. 2, 203-215.

Wetzel, R. G. (1992). Gradientdominated ecosystems: sources and regulatory functions of dissolved organic matter in freshwater ecosystems. Hydrobiologia 229, 181-198.

Wetzel, R. G., and Likens, G. E. (2000). Limnological Analyses, 3rd Edn. New York: Springer-Verlag.

Wu, Q. L., Zwart, G., Wu, J., Kamst-van Agterveld, P., Liu, S., and Hahn, M. W. (2007). Submersed macrophytes play a key role in structuring bacterioplankton community composition in the large, shallow, subtropical Taihu Lake, China. Environ. Microbiol. 9, 2765-2774.

Conflict of Interest Statement: The authors declare that the research was conducted in the absence of any commercial or financial relationships that could be construed as a potential conflict of interest.

Received: 30 August 2012; accepted: 14 December 2012; published online: 04 January 2013.

Citation: They NH, da Motta Marques D and Souza RS (2013) Lower respiration in the littoral zone of a subtropical shallow lake. Front. Microbio. 3:434. doi: 10.3389/fmicb.2012.00434

This article was submitted to Frontiers in Aquatic Microbiology, a specialty of Frontiers in Microbiology. Copyright (C) 2013 They, da Motta Marques and Souza. This is an open-access article distributed under the terms of the Creative Commons Attribution License, which permits use, distribution and reproduction in other forums, provided the original authors and source are credited and subject to any copyright notices concerning any third-party graphics etc. 